\title{
Spatial and Temporal Distribution of Ceratocystis fagacearum in Roots and Root Grafts of Oak Wilt Affected Red Oaks
}

\author{
Ryan A. Blaedow and Jennifer Juzwik
}

\begin{abstract}
The spatial and temporal distributions of the oak wilt fungus, Ceratocystis fagacearum, in the roots of symptomatic and adjacent asymptomatic northern red oaks (Quercus rubra) were investigated. Root systems of 12 pairs of such trees were exposed to $1 \mathrm{~m}$ ( $3.3 \mathrm{ft}$ ) depth using an air excavation tool. In only one case was the fungus found in more than two cardinal directions of symptomatic trees based on isolation attempts from 192 root segments excised from $1.2 \mathrm{~m}(3.5 \mathrm{ft})$ lengths of primary roots extending in four cardinal directions from the root collar. Many (162) self grafts occurred in all oaks. Few (13) inter-tree grafts were found in less than one-third of the tree pairs. The fungus was isolated from the roots involved in two of thirteen inter-tree grafts and 14 of 62 self grafts assayed. The sporadic and unpredictable distribution of the fungus in roots of wilting red oaks supports current control approaches that assume the fungus is present in roots extending out in all directions once crown symptoms are evident. Additionally, self grafts may serve as a conduit for circumferential movement of the fungus around the main stem, but outside the root collar, through the interconnected roots.

Key Words. Ceratocystis fagacearum; Oak Wilt; Quercus rubra; Root Grafts; Vascular Wilt Disease.
\end{abstract}

Oak wilt, caused by the vascular pathogen Ceratocystis fagacearum, is considered the most important disease of oaks (Quercus spp.) in the eastern United States (Tainter and Baker 1996). In the state of Minnesota, U.S., both white oaks (Section Quercus) and red oaks (Section Lobatae) are susceptible to $C$. fagacearum, but the disease is particularly devastating for red oak species including northern red oak (Quercus rubra) and northern pin oak (Quercus ellipsoidalis), which wilt and die within weeks to months of incipient wilt development.

The oak wilt fungus spreads through root grafts or common roots between neighboring oaks, resulting in the formation of expanding areas of wilting and dead trees known as disease centers (Gibbs and French 1980). New disease centers are established via overland transmission of the pathogen to healthy trees by insect vectors, such as sap feeding beetles of the Nitidulidae family. While overland transmission is responsible for longer distance spread of $C$. fagacearum in the landscape, the majority of new infections occur as a result of root graft transmission of the pathogen in expanding disease centers (Juzwik et al. 1985).

Tylose production and gummosis in response to infection, while prolific in the aboveground water-conducting vessel elements, appears to occur at a relatively low rate in the roots of infected trees even after tree death. Thus the spread of the fungus proceeds relatively uninhibited through roots and root grafts (Struckmeyer et al. 1954; Yelenosky and Fergus 1959; Nair and Kuntz 1975). Inoculation studies have shown the length of time between root inoculations and incipient wilt development ranges from several weeks to several years (Yount 1955; Yount 1958; Skelly and Wood 1974a; Rexrode 1978). This suggests the rate of movement of $C$. fagacearum through roots is variable, and that the pathogen is capable of surviving undetected in the roots of apparently healthy trees for many years (Yount 1958; Skelly and Wood 1974a). This hypothesis was supported when dyes injected into $C$. fagacearum infected trees helped to definitively confirm the presence of root grafts, and yet disease symptoms were not observed in grafted trees for up to three years after the death of the initially infected tree (Rexrode 1978). The frequency of parasitic interactions between the pathogen and parenchymatous root cells was found to be relatively low, and the survival of the fungus in roots for long periods is not well understood (Struckmeyer et al. 1958). Longevity of the fungus in the root systems of trees that succumbed to oak wilt may be aided by water and nutrients supplied through root grafts to healthy trees (Yount 1955).

The frequency of root graft transmission is influenced by soil, host, and stand characteristics and may vary widely between regions or on more local scales (Gibbs and French 1980; Bruhn et al. 1991). Attempts to characterize oak wilt spread in disease centers have been made in the United States in Michigan's Upper Peninsula (Bruhn et al. 1991), southern Wisconsin (Menges and Kuntz 1985), North Carolina (Boyce 1960), Texas (Appel et al. 1989), and Missouri (Jones and Partridge 1961). Management guidelines developed as a result of these investigations have increased the efficacy of integrated management strategies for oak wilt in those regions. However, applying these guidelines outside regions where the disease spread was modeled can lead to reduced or inconsistent control.

Root graft transmission in Minnesota is managed by mechanically severing grafted root systems, most commonly with a vibratory plow, thus establishing a "root graft barrier" (French and Juzwik 1999). Effective root graft barrier placement is difficult because the pathogen must be contained within the disease center while sacrificing as few healthy oaks as possible within the 
barrier line. Pathogen distribution in the root system of trees in or near disease centers cannot be determined reliably based on symptom development above ground, so "primary" lines are installed to contain the pathogen effectively and "secondary" lines are placed within the primary line in an attempt to save healthy oaks in close proximity to wilting ones (French and Juzwik 1999).

Systemic fungicides such as propiconazole have been used to protect oaks in situations where, for example, a vibratory plow cannot be used to mechanically disrupt root grafts (Appel 2001). Propiconazole applications also provide additional protection for high value asymptomatic trees within root graft barrier lines (Juzwik et al. 2004). However, propiconazole has not been shown to prevent root graft transmission; rather it is believed to prevent disease development through an, as yet, undetermined means.

Management of oak wilt via control of root graft transmission of $C$. fagacearum has the potential to be more efficacious should managers achieve a more thorough understanding of pathogen movement into and colonization of the root system, because treatments are directed at preventing infection of healthy trees that generally do not show symptoms immediately following root infection. These latent infections are a substantial obstacle to oak wilt management. They can lead to costly treatment failures, for example, in situations where the pathogen has already spread beyond root graft barrier lines at the time of treatment or when disease development occurs in chemically-treated oaks following fungicide degradation, and can put additional trees at risk that are normally not considered in management regimes.

The spatial distribution of $C$. fagacearum in the near-surface roots of wilted or wilting northern red oaks and proximal asymptomatic northern red oaks was investigated in east-central Minnesota. Field studies involving pairs of oak wilt symptomatic and asymptomatic trees were conducted in 2005 and 2006 to determine: 1) the presence of the pathogen in primary roots (roots originating directly from the root collar) in wilting trees, 2) the frequency of inter-tree grafts and self grafts (grafts between two roots of the same tree) within $1 \mathrm{~m}(3.3 \mathrm{ft})$ of the soil surface, and 3$)$ the presence of the pathogen in roots joined in functional root grafts. A preliminary report has been published (Blaedow and Juzwik 2007).

\section{MATERIALS AND METHODS}

\section{Experimental Design}

The field study was conducted at 12 sites, each with an active disease center, within the Carlos Avery Wildlife Refuge in Chisago County in east-central Minnesota. All sites were located on Zimmerman loamy sand or Sartell fine sand, and northern red oak was the predominant species. Wilt development of individual northern red oaks in disease centers was monitored between 2004 and 2006. A pair of trees consisting of one diseased tree and the nearest asymptomatic tree were selected from each disease center during this time period. The diseased trees were suspected to have been infected via root graft transmission of the pathogen because of their close proximity $(<5 \mathrm{~m} ; 16.4 \mathrm{ft})$ to actively wilting or recently wilted trees. The extent of pathogen distribution in the root system of wilting trees and the incidence of root graft transmission to the neighboring asymptomatic tree was expected to increase with increasing symptom progression. Therefore a minimum of two diseased trees from each of the following stages of crown wilt (percent of crown displaying symptomatic foliage) were selected for this study: 1) $20 \%-40 \%$ crown wilt, 2) $41 \%-85 \%$ crown wilt, 3) 86\%-99\% crown wilt, and 4) $100 \%$ crown wilt for 12-14 months (dead). The diameter at breast height (dbh) of selected trees ranged from 12.7-63.5 cm (5-25 in); average dbh was 31.2 $\mathrm{cm}$ (12.3 in) (Table 1). Distance between trees within a pair ranged from 0.4-4.6 m (1.3-15.1 ft); average distance was $2.6 \mathrm{~m}(8.5 \mathrm{ft})$.

\section{Root Excavation and Sampling}

Partial root system excavation of each of the 24 selected trees (12 pairs of diseased and proximal asymptomatic trees) was conducted with an air excavation tool (Airspade ${ }^{\circledR}$, Guardair Corp, Chicopee, MA). After removing approximately the upper $15 \mathrm{~cm}$ (6 in) of soil containing fine roots and understory plants, the underlying mineral soil was removed while leaving the root system of study trees intact and undamaged. At the selected field sites, the roots of the red oaks had frequently grown at a high angle of descent, beyond one meter below grade. However, the maximum excavation depth that could be efficiently achieved in the sandy soil with the excavation tool was approximately one meter.

One primary root in each quadrant of the four cardinal directions was sampled to investigate the spatial distribution of the pathogen in each tree. Root segments approximately $10 \mathrm{~cm}(3.9$ in) in length were removed from each primary root at $0.3,0.6$, 0.9 , and $1.2 \mathrm{~m}(1,2,3$, and $3.9 \mathrm{ft})$ from the root collar. The incidence of root grafting between pairs of trees was also examined at each site. All soil was removed from an initial search area $3 \mathrm{~m}$ $(9.8 \mathrm{ft})$ wide that spanned the distance between the wilting and

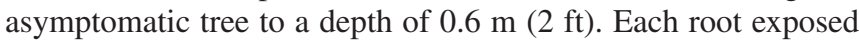
in the initial search area was examined beginning at the root collar of the originating tree until one of the following conditions were met: 1) the root grafted to the root of a neighboring tree, 2) the root descended to a depth greater than $1 \mathrm{~m}$ below grade, 3) the root diameter tapered to less than $1 \mathrm{~cm}(0.4 \mathrm{in})$, or 4$)$ the

Table 1. Numbers of primary roots yielding Ceratocystis fagacearum by crown condition of sampled northern red oak.

\begin{tabular}{|c|c|c|c|c|c|}
\hline \multirow{3}{*}{$\begin{array}{l}\text { Crown wilt } \\
\text { stage } \\
\text { (percent wilt) }\end{array}$} & \multirow{3}{*}{$\begin{array}{l}\text { Number of } \\
\text { trees } \\
\text { sampled }\end{array}$} & \multicolumn{2}{|c|}{ Number of primary roots ${ }^{z y}$} & \multirow{2}{*}{\multicolumn{2}{|c|}{$\begin{array}{l}\text { Number of primary roots per tree } \\
\text { yielding Ceratocystis fagacearum }\end{array}$}} \\
\hline & & \multirow[t]{2}{*}{ Assayed } & \multirow{2}{*}{$\begin{array}{l}\text { Yielding } \\
\text { fungus }\end{array}$} & & \\
\hline & & & & Mean & Maximum \\
\hline Asymptomatic & 12 & 48 & 2 & 0.2 & 2 \\
\hline $20-40$ & 2 & 8 & 4 & 2 & 2 \\
\hline $41-85$ & 4 & 16 & 6 & 1.5 & 4 \\
\hline $86-99$ & 4 & 16 & 4 & 1 & 2 \\
\hline Dead & 2 & 8 & 2 & 1 & 2 \\
\hline
\end{tabular}

${ }^{\mathrm{z}}$ Four primary roots were sampled from each northern red oak, and the incidence of $C$. fagacearum was determined by isolation from four $10 \mathrm{~cm}$ ( 3.9 in) long sub-samples taken at $0.3 \mathrm{~m}(1 \mathrm{ft})$ intervals from the root collar.

y The number of primary roots yielding $C$. fagacearum was similar for all crown wilt stages $(\mathrm{P}=0.2874)$. 
root significantly deviated from a course that would have led into the canopy drip line of the proximal tree. If an inter-tree graft between the two paired trees was discovered, root segments approximately $10 \mathrm{~cm}$ in length were removed from both roots involved in the graft union at $0.3 \mathrm{~m}(1 \mathrm{ft})$ intervals beginning at the root graft to the root collar. Within the total excavated area between the two trees, samples were also taken from roots involved in self grafts when present. Inter-tree and self-grafts were also sampled from the excavated primary roots described above. For each excavated root system, the length of all exposed roots that could be successfully traced back to the root collar, the number of inter-tree and self-grafts discovered, and the linear distance of grafts along the root from the root flare were recorded. Intertree grafting was confirmed by removal of bark and outer layers of vascular tissue to confirm continuity of the vascular system across the root graft union between the two roots involved.

All root samples were sealed in plastic bags and placed into cold storage $\left(4^{\circ} \mathrm{C}\right.$ or $\left.37^{\circ} \mathrm{F}\right)$ shortly after removal from the soil. Root samples were assayed for the presence of $C$. fagacearum two to three weeks after collection. During laboratory processing, root samples were surface sterilized with $95 \%$ ethanol and briefly flamed. Small wood chips approximately $0.5 \mathrm{~cm}(0.2$ in) in length were removed from outer rings of xylem along the length of the root segment. Chips were plated onto $10 \%$ lactic acid-amended potato dextrose agar and incubated in the dark at $25^{\circ} \mathrm{C}\left(77^{\circ} \mathrm{F}\right)$ for 30 days. Plates were examined weekly for the presence of $C$. fagacearum. Colony appearance and asexual spore characteristics were used to identify the fungus (Barnett 1953). A second attempt to isolate the pathogen was made from any root segments which did not yield the pathogen from the first attempt.

\section{Data Analysis}

The effects of tree wilt category and distance of root segments from the root collar on the incidence of $C$. fagacearum were analyzed by analysis of variance (ANOVA) using the general linear model procedure (PROC GLM) in SAS (SAS Institute, Inc. Cary, NC). Differences between means were determined using Tukey's $w$ procedure $(\alpha=0.05)$.

\section{RESULTS}

\section{Pathogen Presence in Primary Roots}

Overall, C. fagacearum was isolated from $18.7 \%(\mathrm{n}=96)$ of the primary roots excavated and assayed (Table 1). More specifically, the pathogen was isolated from $27.5 \%(\mathrm{n}=192)$ of root segments from symptomatic (wilting or dead) trees and from $1 \%(\mathrm{n}=192)$ of root segments from asymptomatic trees (Table 2). In the latter case, $C$. fagacearum was isolated from one asymptomatic red oak $(24.1 \mathrm{~cm} ; 9.5 \mathrm{in} \mathrm{dbh})$ that was $4.6 \mathrm{~m}(15.1 \mathrm{ft})$ west of a red oak $(30.7 \mathrm{~cm} ; 12.1 \mathrm{in} \mathrm{dbh})$ that exhibited $100 \%$ crown wilt at the time of excavation. This tree had started wilting only two months prior (i.e., in mid-June). In the nearby wilted tree, the pathogen was isolated from all segments of the root nearest the asymptomatic tree; however, no grafts were found in the excavated zone between the two trees. In the asymptomatic tree, the pathogen was sporadically distributed. The fungus was isolated from only one segment of each of the northern and southern originating roots.

The number of primary roots from each tree yielding the pathogen was similar for all categories of symptomatic (wilting or dead) trees $(\mathrm{P}=0.2874)$ (Table 1$)$. In all but one case, $C$. $f a$ gacearum was isolated from no more than two of the primary roots extending in each cardinal direction from the tree stem. The exception was an oak with $60 \%$ crown wilt which yielded the pathogen in primary roots from all four cardinal directions. This tree was $4 \mathrm{~m}(13.1 \mathrm{ft})$ from two trees $(35.6 \mathrm{~cm}$ and $40.6 \mathrm{~cm} ; 14$ in and 16 in dbh) that had completely wilted the previous year.

Within each crown wilt stage for actively wilting trees, the proportions of root segments yielding $C$. fagacearum were not correlated with distance from the root collar $(0.3$ to $1.2 \mathrm{~m}$; 1 to $2 \mathrm{ft}$ ) ( $\mathrm{P} \geq 0.3351)$. Pair-wise comparisons of those proportions within each distance category and for all categories combined revealed several significant differences $(\alpha=0.05)$ (Table 2 ). The frequency of segments yielding the pathogen increased as distance from the root collar increased in dead trees $(\mathrm{P}=$ 0.0422) (Table 2). During all stages of crown wilt, in the majority of roots from which the pathogen was successfully isolated $(77.7 \%, \mathrm{n}=18)$, at least one-half of the four root subsamples yielded the fungus, but $C$. fagacearum was only isolated from all four subsamples of pathogen-yielding roots in $44.4 \%$ of cases.

\section{Root Graft Occurrence}

Eleven inter-tree root grafts were found along $514 \mathrm{~m}(1,686 \mathrm{ft})$ of roots excavated between pairs of 12 wilting/wilted oaks and their closest asymptomatic neighbors. The grafts occurred between three of the twelve tree pairs and most grafts involved either primary or secondary roots (Table 3 ). Two additional grafts were discovered during excavations of a single symptomatic/ asymptomatic pair of trees, but the grafts were traced from the symptomatic tree to another oak (also symptomatic) that was not

Table 2. Mean percent of primary root segments that yielded Ceratocystis fagacearum by sampling distance from the root collar and crown wilt stage.

\begin{tabular}{|c|c|c|c|c|c|c|c|}
\hline \multirow{3}{*}{$\begin{array}{l}\text { Crown wilt } \\
\text { stage } \\
\text { (percent wilt) }\end{array}$} & \multicolumn{2}{|c|}{ Number assessed ${ }^{\mathrm{z}}$} & \multirow{2}{*}{\multicolumn{5}{|c|}{$\begin{array}{l}\text { Mean percent of root segments yielding Ceratocystis fagacearum by distance } \\
\text { from root collar }(\mathrm{m})^{\mathrm{y}}\end{array}$}} \\
\hline & \multirow{2}{*}{ Trees } & \multirow{2}{*}{$\begin{array}{l}\text { Root } \\
\text { segments }\end{array}$} & & & & & \\
\hline & & & 0.3 & 0.6 & 0.9 & 1.2 & Total \\
\hline Asymptomatic & 12 & 192 & $2.1 \mathrm{e}$ & $2.1 \mathrm{e}$ & $0.0 \mathrm{e}$ & $0.0 \mathrm{e}$ & $1.1 \mathrm{D}$ \\
\hline $20-40$ & 2 & 32 & $50.0 \mathrm{a}$ & $50.0 \mathrm{a}$ & $50.0 \mathrm{a}$ & $25.0 \mathrm{bc}$ & $43.8 \mathrm{~A}$ \\
\hline $41-85$ & 4 & 64 & $31.3 \mathrm{~b}$ & $25.0 \mathrm{bc}$ & $18.8 \mathrm{~cd}$ & $25.0 \mathrm{bc}$ & $25.0 \mathrm{~B}$ \\
\hline $86-99$ & 4 & 64 & $25.0 \mathrm{bc}$ & $25.0 \mathrm{bc}$ & $18.8 \mathrm{~cd}$ & $18.8 \mathrm{~cd}$ & $21.5 \mathrm{~B}$ \\
\hline Dead & 2 & 32 & $0.0 \mathrm{e}$ & $12.5 \mathrm{~d}$ & $25.0 \mathrm{bc}$ & $25.0 \mathrm{bc}$ & $15.5 \mathrm{C}$ \\
\hline
\end{tabular}

${ }^{\mathrm{z}}$ Four roots were sampled from each northern red oak, and the incidence of $C$. fagacearum was determined by isolation from $10 \mathrm{~cm}$ ( 3.9 in) long sub-samples taken at 0.3 $\mathrm{m}(1 \mathrm{ft})$ intervals from the root collar.

${ }^{y}$ Means with the same letter within each column are not significantly different ( $\alpha=0.05$, Tukey's $w$ test) for percent of root segments yielding $C$. fagacearum by distance (a-e) and total segments (A-E) 
originally included in the study. Over $30 \%(\mathrm{n}=21)$ of grafted roots were involved in more than one inter-tree graft. Of the seven roots involved in more than one root graft, three roots were involved in two grafts, two roots were involved in three grafts, and one root was grafted at four different locations to other roots. Thus, the number of inter-tree grafted roots $(n=21)$ is less than the expected number $(n=26)$ for 13 grafts, because 7 of the grafted roots were involved in more than one inter-tree root graft.

Table 3. Number, order and total length of roots excavated and the number of roots involved in inter-tree root grafting based on the occurrence of 13 inter-tree grafts found between four pairs of northern red oaks within $1.0 \mathrm{~m}$ ( $3.3 \mathrm{ft})$ of the soil surface.

\begin{tabular}{llll}
\hline Root Order & $\begin{array}{l}\text { Number of roots } \\
\text { examined }\end{array}$ & $\begin{array}{l}\text { Length of roots } \\
\text { examined }(\mathrm{m})\end{array}$ & $\begin{array}{l}\text { Number of roots } \\
\text { involved in } \\
\text { inter-tree grafts }\end{array}$ \\
\hline Primary & 174 & 306 & 12 \\
Secondary & 259 & 144 & 7 \\
Tertiary & 85 & 64 & 2 \\
Total & 518 & 514 & 21 \\
\hline
\end{tabular}

${ }^{\mathrm{z}}$ In several instances, individual roots were involved in more than one inter-tree graft.

All of the inter-tree grafts occurred within $2.5 \mathrm{~m}(5.2 \mathrm{ft})$ of the root collar of both trees in the pair, but all grafts occurred within $1 \mathrm{~m}$ of the root collar of at least one tree in the pair (Figure 1). The average distance between grafted pairs of trees was

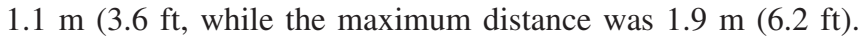
Many "false grafts" were found (e.g., superficial grafts where continuity of the vascular system across the union was absent).

Self grafts were observed in all 24 root systems. A total of 162 self grafts were found along the same length of roots examined for inter-tree grafts. They were prevalent in close proximity to the root collar where the density of roots was the highest (Figure 2a); however, self grafts were found among all root orders and up to five meters from the stem. The frequency of self grafts was positively correlated with tree diameter (Figure $2 b)$. No "false grafts" were found among the observed self grafts.

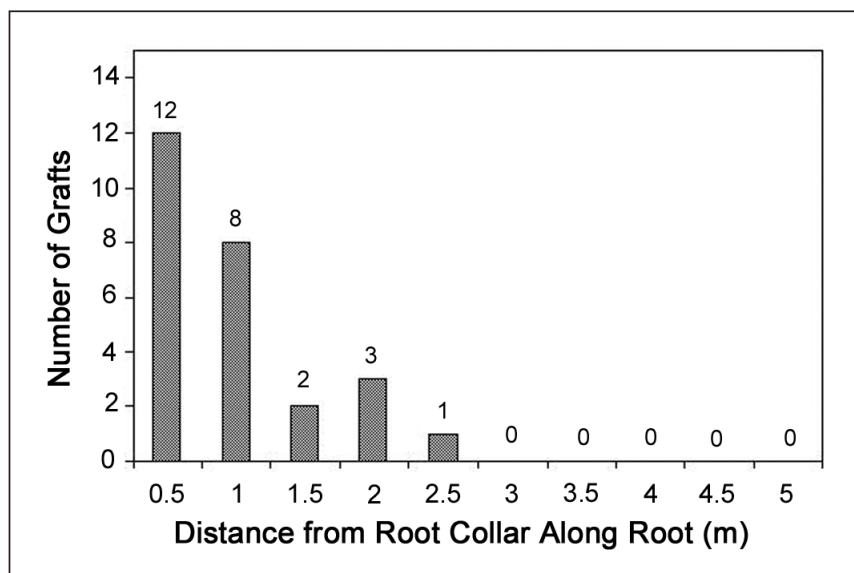

Figure 1. Frequencies of inter-tree root graft by distance from the root collar as measured along the length of each root involved in the graft union. Data represent 13 inter-tree grafts found between four pairs of northern red oaks within $1 \mathrm{~m}(3.3 \mathrm{ft})$ of the soil surface. Each inter-tree graft is represented by two measurements, one for each root involved in the graft union.

\section{Pathogen Presence in Root Grafts}

Tissue samples taken in close proximity to inter-tree graft unions yielded the pathogen in two of the thirteen inter-tree grafts. However, both grafts testing positive for $C$. fagacearum were the two grafts found inadvertently between a symptomatic study tree and a symptomatic nonstudy tree $(1.9 \mathrm{~m} ; 6.2 \mathrm{ft}$ apart) as described above. The study tree $(25.4 \mathrm{~cm} ; 10$ in $\mathrm{dbh})$ had begun to wilt in early July 2005 and was $100 \%$ wilted at the time of excavation in August 2005, while the non-study tree $(12.7 \mathrm{~cm} ; 5$ in $\mathrm{dbh})$ was $20 \%$ wilted. In both grafts, the pathogen was found in both roots involved in the graft union.

C. fagacearum was isolated from 13 of 62 self grafts assessed for presence of the pathogen. Eleven of those self grafts yielded $C$. fagacearum in both roots of the graft union, while the pathogen was found in only one root in the other two cases.

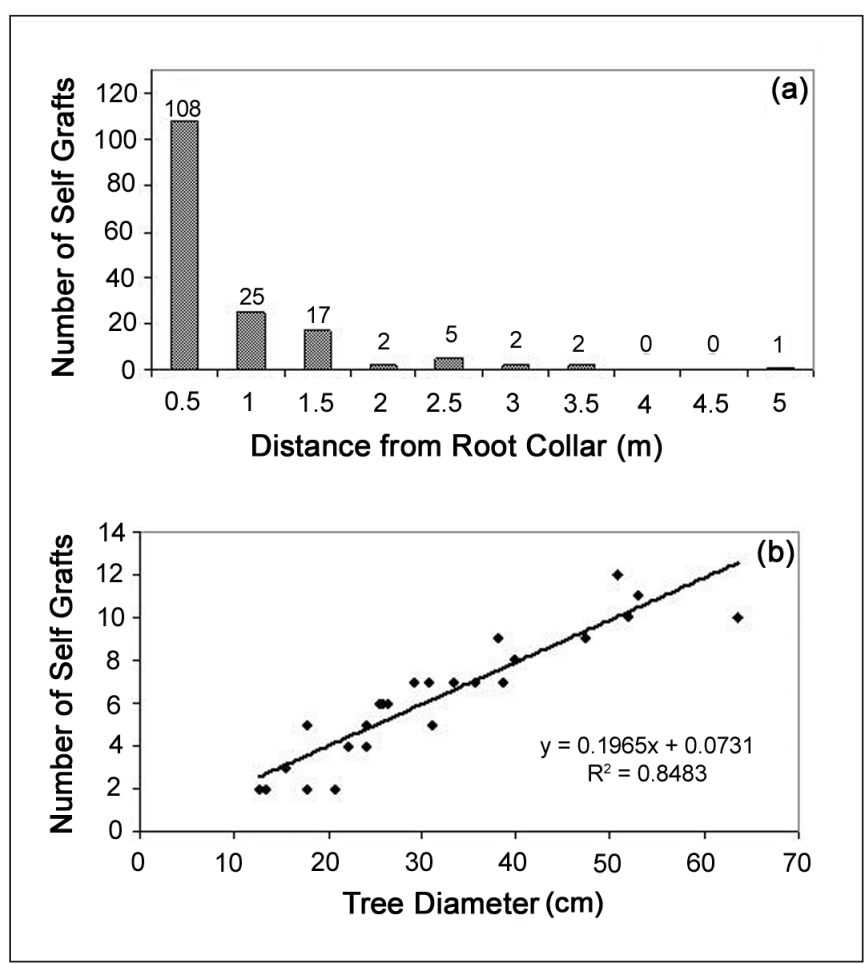

Figure 2. Self grafts $(n=162)$ observed in root systems of northern red oaks. A) Frequency of occurrence by distance from the root collar (m), and B) Number of self-grafts per red oak by stem diameter $(\mathrm{cm})$ at breast height $(1.4 \mathrm{~m})$.

\section{DISCUSSION}

Absence of $C$. fagacearum from the root system of asymptomatic trees in close proximity $(0.5-4.6 \mathrm{~m} ; 1.6-15.1 \mathrm{ft})$ to wilting or wilted trees, and from the majority of sampled primary roots of dead or diseased trees in the most advanced stages of disease progression, suggests pathogen distribution in the root system may not be widespread. Alternatively, extensive pathogen colonization of the root system may require months or years following tree death, a hypothesis that seems to be supported, at least in certain cases, by latent spread of the fungus over the course of many years between wilted and healthy trees (Skelly and Wood 1974a; Skelly and Wood 1974b). 
Slow movement of the pathogen into the root system during wilting or following tree death could be explained by the necessity for spread via vegetative growth. In other cases the pathogen is found in roots more rapidly than could be accounted for by vegetative growth (even at the earliest stages of incipient wilt); it has been suggested the negative water potential generated by healthy, actively transpiring trees grafted to the wilting tree may draw pathogen propagules from the diseased tree into the root system and across root grafts (Nair and Kuntz 1975). Rapid movement into a few grafted roots, as opposed to colonization of the entire root system via vegetative growth, could explain the sporadic distribution of the pathogen in primary roots of diseased or dead oaks. The study authors did not attempt isolations from all primary roots, so it is possible pathogen distribution in the root system is more widespread than the results indicate. The distribution of $C$. fagacearum observed in this investigation suggests colonization of the root system in wilting or wilted trees is limited however.

In dead trees, absence of the pathogen near the root collar may be due to displacement of $C$. fagacearum by more efficient saprophytes. Presence of the pathogen did increase with increasing distance from the root collar in the dead trees, likely because moisture availability and temperature are more suitable for pathogen survival with increasing distance from the soil surface (Tainter 1995).

While there was no attempt to examine the entire root system of the study trees, the frequency of inter-tree grafting, particularly between trees in close proximity to one another $(<5 \mathrm{~m})$, in sandy soils, was surprisingly low. Large portions of the root systems of most excavated trees appeared to be distributed well below $1 \mathrm{~m}$ of the soil surface (the maximum depth examined in this study). Inter-tree grafting in the upper $1 \mathrm{~m}$ of soil was a relatively infrequent phenomenon when compared to the incidence of selfgrafting. However, inter-tree graft occurrence is likely frequent enough to account for the rate of expansion of disease centers observed in sandy soils. In North Carolina, U.S., Boyce (1960) was only able to locate three inter-tree root grafts between 42 wilting oaks and proximal wilt-killed trees, and only one of these grafts was shown to be the pathway for infection. Yet, the author noted that $96 \%$ of wilting oaks in the state were within $15 \mathrm{~m}$ (50 ft) of wilt-killed trees, suggesting that root graft transmission was the primary mode of infection. In the state of Missouri, a slightly higher percentage of black oaks $(16 \%)$ and white oaks (20\%) were found to be grafted to other trees (Jones and Partridge 1961). Parmeter et al. (1956) reported over $70 \%$ of northern pin oaks in stands on deep sand soils in central Wisconsin were grafted. Therefore, it is likely that inter-tree grafts on sites such as those used in this study may exist below the range of the excavation equipment, as well as that of vibratory plows and trenchers commonly used for the installation of root graft barrier lines.

Self grafts, while rarely discussed in the literature, may play an important role in pathogen transmission in the root systems of oaks. In this investigation, the results of isolations from self grafts demonstrate that the pathogen is able to readily move from root to root through self grafts. Therefore, lateral spread of $C$. fagacear$u m$ from one root to another may not require pathogen movement into the root collar zone, but could occur through networks of self grafts. Such a mechanism of pathogen movement could allow the fungus to spread throughout large portions of the root system while bypassing the root collar zone where systemic chemical treatments are applied. It was previously believed that translocation of propiconazole into roots following injection is limited and does not prevent infection via root grafts (Appel 2001). Recently however, high concentrations of propiconazole in primary roots following macro-infusion treatment have been observed (Blaedow 2009). Substantial acropetal transport of propiconazole from the point of injection into the upper portion of the tree seems to prevent wilt development in infected trees. If systemic fungicides such as propiconazole move downward into the roots (even short distances) following injection, it could provide the added benefit of limiting latent root system colonization in infected trees because of the prevalence of self grafts within $1 \mathrm{~m}$ of the root collar. Xylemmobile dyes have been found to move downward into xylem of woody roots of red oak and eight other tree species (Tattar 2009).

\section{CONCLUSIONS}

The results of this study reveal the sporadic and unpredictable distribution of $C$. fagacearum in the root systems of wilted and wilting trees. Based on these results, distribution of the oak wilt pathogen in the root systems of diseased or neighboring asymptomatic trees cannot reliably be determined by assessment of aboveground symptoms. Current control approaches assume the pathogen is present in all roots at the time of symptom appearance, and call for conservative placement of root graft barriers and preventative chemical treatments that account for latent infections are warranted. The frequent inability to isolate $C$. $f a$ gacearum from the root system of diseased trees, even from trees that had died the previous growing season, suggests pathogen movement into and subsequent colonization of the root system may take months or years following tree death in most cases.

Even when efforts are made to prevent root graft transmission, and connected root systems between diseased and asymptomatic trees are severed, it may be possible for latent infections in asymptomatic trees result in pathogen movement beyond vibratory plow lines or trenches, enabling disease development outside such zones. Chemical treatments, such as propiconazole, which do not prevent root graft transmission but prevent disease development (Blaedow 2009), may allow latent colonization of root systems and even transmission to neighboring trees. Following the period of protection provided by chemical treatments, generally less than two years, disease development may be initiated as a result of masked infections. However, propiconazole translocation into roots could limit pathogen colonization of large portions of the root system and spread to uninfected trees if distribution of the fungicidal compound is sufficient to prevent pathogen spread out of inter-tree grafted roots containing the invading pathogen into self grafts and the root collar.

\footnotetext{
Acknowledgments. This project was funded by several sources: Tree Research and Education Endowment Fund, Rainbow Treecare Scientific Advancements, the U.S. Forest Service Pesticide Impact and Assessment Program, and the U.S. Forest Service North Central Research Station. We thank Paul Castillo for excellent field support and Dr. Robert Blanchette, Dr. William Chaney, and Dr. Richard Zeyen for review of the manuscript. We also thank Dr. Joseph O'Brien for review and discussion on earlier versions of the manuscript. The paper is based on a portion of a Ph.D. Thesis by the first author.
} 
Disclaimer. Mention of a trademark, proprietary product, or vendor does not constitute a guarantee or warranty of the product by the USDA and does not imply its approval to the exclusion of other products or vendors that may also be suitable.

\section{LITERATURE CITED}

Appel, D.N. 2001. The use of Alamo for oak wilt management, pp. 101106. In: C.L. Ash (Ed.). Shade Tree Wilt Diseases. APS Press, St. Paul, MN.

Appel, D.N., R.C. Maggio, E.L. Nelson, and M.J. Jerger. 1989. Measurement of expanding oak wilt centers in live oak. Phytopathology 79:1318-1322.

Barnett, H.L. 1953. Isolation and identification of the oak wilt fungus. West Virginia University Agriculture Experiment Station Bulletin 359T.

Blaedow, R.A. 2009. Use of the Systemic Fungicide Propiconazole for Oak Wilt Management: An Assessment of Uncharacterized Host Pathogen - Fungicide Interactions. Ph.D. Thesis. University of Minnesota, Department of Plant Pathology. $118 \mathrm{pp}$.

Blaedow, R., and J. Juzwik 2007. Oak wilt pathogen presence in roots and root grafts of diseased red oaks. Phytopathology 97:S10.

Boyce, J.S. 1960. Distribution of Ceratocystis fagacearum in roots of wilt-infected oaks in North Carolina. Phytopathology 50:775-776.

Bruhn, J.N., J.B. Pickens, and D.B. Stanfield. 1991. Probit analysis of root graft transmission through root grafts in red oak stands. Forest Science 37:28-44.

French, D.W., and J. Juzwik. 1999. Oak Wilt in Minnesota. MI-3174-Z. University of Minnesota Extension Service, St. Paul, Minnesota. 6 pp.

Gibbs, J.N., and D.W. French. 1980. The transmission of oak wilt. Research Paper NC-185. USDA Forest Service, North Central Forest Experiment Station, St. Paul, Minnesota. 17 pp.

Jones, T.W., and A.D. Partridge. 1961. The importance of root grafts in oak wilt spread in Missouri. Plant Disease Reporter 45:506-507.

Juzwik, J., S. Cook, L. Haughan, and J. Elwell. 2004. Oak Wilt: People and Trees: A Community Approach to Management. General Technical Report NC-240, St. Paul, MN: U.S. Department of Agriculture, Forest Service, North Central Research Station. CD-ROM. V. 1.3.

Juzwik, J., D.W. French, and J. Jeresek. 1985. Overland spread of the oak wilt fungus in Minnesota. Journal of Arboriculture 11:323-327.

Menges, E.S., and J.E. Kuntz. 1985. Predictive equations for local spread of oak wilt in southern Wisconsin. Forest Science 31:43-51.

Nair V.M.G., and J.E. Kuntz. 1975. Recent advances in oak wilt research, pp. 231-240. In: Advances in Mycology and Plant Pathology. Sager Printers, Jantar Mantar Road, New Delhi, India.

Parmeter, J.R., J.E. Kuntz, and A.J. Riker. 1956. Oak wilt development in bur oaks. Phytopathology 46:423-435.
Rexrode, C.O. 1978. Movement of oak wilt fungus in a tracer solution under pressure through root grafts. Plant Disease Reporter 62: 982-984.

Skelly, J.M., and F.A. Wood. 1974a. Oak wilt development in red oaks following root inoculations with Ceratocystis fagacearum. Plant Disease Reporter 58:738-742.

Skelly, J.M., and F.A. Wood. 1974b. Longevity of Ceratocystis fagacearum in ammate treated and nontreated root systems. Phytopathology 64:1483-1485.

Struckmeyer, B.E., B. Esther, and J.E. Kuntz. 1954. Histology of fungus mat development in wilting oak trees. Phytopathology 44:507.

Struckmeyer, B.E., J.E. Kuntz, and A.J. Riker. 1958. Histology of certain oaks infected with the oak wilt fungus. Phytopathology 48:556-561.

Tainter, F.H. 1995. Host $\times$ Parasite Interactions. pp. 47-53. In: Oak Wilt Perspectives: The proceedings of the National Oak Wilt Symposium, June 22-25, 1992, Austin, Texas. Information Development Inc., Houston, TX.

Tainter, F.H., and F.A. Baker. 1996. Oak Wilt. pp. 671-682. In: Principles of Forest Pathology. John Wiley and Sons, New York, New York.

Tattar, T.A. 2009. Injection, infusion, and systemic movement in trees. pp. 169-173. In: Proceedings of the National Oak Wilt Symposium, June 4-7, 2007, Austin, TX. Texas Forest Service Publication 166. 267 pp.

Yelenosky, G., and C.L. Fergus. 1959. Absorption and translocation of solutions by healthy and wilt-diseased red oaks. Bulletin 657. Pennsylvania State University Agricultural Experiment Station, University Park, Pennsylvania. 18 pp.

Yount, W.L. 1955. Longevity of the oak wilt fungus in oak roots as related to spread through root grafts. Plant Disease Reporter 39:256-257.

Yount, W.L. 1958. Results of root inoculations with the oak wilt fungus in Pennsylvania. Plant Disease Reporter 42:548-551.

Ryan A. Blaedow

North Carolina Division of Forest Resources

762 Claridge Nursery $R d$.

Goldsboro, NC 27530, U.S.

ryan.blaedow@ncdenr.gov

Jennifer Juzwik (corresponding author)

U.S. Forest Service

Northern Research Station

1561 Lindig Street

St. Paul, MN 55108, U.S

jjuzwik@fs.fed.us 
Résumé. La distribution spatiale et temporelle de la flétrissure du chêne, Ceratocystis fagacearum, dans les racines de chênes rouges (Quercus rubra) symptomatiques et asymptomatiques adjacents a été étudiée. Les systèmes racinaires de 12 paires de ces arbres ont été exposés à 1 $\mathrm{m}$ de profondeur au moyen d'un outil à excavation à l'air. Dans seulement un cas le champignon a été retrouvé sur plus de deux côtés d'arbres symptomatiques, et ce en se basant sur des tentatives d'isolation à partir de 192 segments de racines excisés de 1,2 $\mathrm{m}$ de longueur provenant de racines primaires qui s'étaient développer dans les quatre directions depuis le collet racinaire. Plusieurs (162) greffes libres se sont produites chez tous les chênes. Peu (13) de greffes inter-arbres ont été observées, et ce sur moins du tiers des paires d'arbres. Le champignon a été isolé des racines provenant de deux des treize arbres inter-greffés et sur 14 des 62 arbres greffés librement qui ont été testés. La distribution sporadique et non prédictible des champignons dans les racines de chênes atteints de flétrissure permet de supporter les approches courantes de contrôle qui assument que le champignon est alors présent dans toutes les directions lorsque les symptômes au niveau de la couronne deviennent évidents. De plus, les greffes libres peuvent servir de voie pour le mouvement circonférentiel du champignon autour de la tige principale, mais en dehors du collet racinaire, au travers des racines interconnectées.

Zusammenfassung. Die räumliche und zeitliche Ausbeitung von Eichenwelke in den Wurzeln befallener und benachbarter unbefallener Roteichen wurde hier untersucht. Die Wurzelsysteme von 12 solcher Baumpaare wurden ca. $1 \mathrm{~m}$ tief freigelegt. Basierend auf einer Isolation aus 192 Wurzelsegmenten von 1,2 m langen Primärwurzeln aus vier Hauptrichtungen vom Wurzelkragen ausgehend wurde der Pilz nur in einem Fall in mehr als zwei Hauptrichtungen gefunden. Es wurden viele (162) Wurzelverbindungen bei allen Eichen gefunden. Einige (13) Verbindungen zwischen zwei verschiedenen Bäumen wurden in weniger als einem Drittel der Baumpaare gefunden. Der Pilz wurde aus den Wurzeln aus zwei von dreizehn Verbindungen zwischen zwei Bäumen und 14 von 62 baumeigenen Wurzelverbindungen isoliert. Die sporadische und unvorhersehbare Ausbreitung des Pilzes in den Wurzeln von welkenden Eichen unterstützt die gegenwärtigen Kontrollversuche, die davon ausgehen, daß sich der Pilz, wenn er einmal die Wurzeln befallen hat und Welke zu sehen ist, in alle Richtungen ausbreitet. Darüberhinaus können diese Wurzelverwachsungen auch dafür verantwortlich sein, wie sich der Pilz im Wurzelwerk um den betroffenen Baumherum ausbreitet, und außerhalb des Wurzelkranzes durch Wurzelverbindung mit benachbarten Bäumen.

Resumen. Se investigó la distribución espacial y temporal del hongo del marchitamiento del encino, Ceratocystis fagacearum, en las raíces de encinos rojos norteños sintomáticos y asintomáticos (Quercus rubra). Los sistemas de raíces de 12 pares de estos encinos fueron expuestos, a $1 \mathrm{~m}(3.3 \mathrm{ft})$ de profundidad, usando una espada de aire. En solamente un caso se encontró el hongo en más de dos direcciones cardinales de árboles sintomáticos, con base en asilamientos de 192 segmentos de raíces de $1.2 \mathrm{~m}$ ( $3.5 \mathrm{ft})$ de longitud de raíces primariamente extendidas en cuatro direcciones cardinales del collar. Ocurrieron muchos (162) auto-injertos en todos los encinos. Se encontraron pocos (13) injertos entre árboles en menos de una tercera parte de los árboles. Los hongos fueron aislados de las raíces en dos de trece injertos entre árboles y 14 de 62 auto-injertos. La distribución esporádica e impredecible de los hongos de marchitamiento en raíces de encinos rojos soporta el control actual que asume que el hongo está presente en las raíces que se extienden en todas las direcciones una vez que los síntomas en la corona son evidentes. Adicionalmente, los auto-injertos pueden servir como conductos para el movimiento circunferencial de los hongos alrededor del tronco principal, pero afuera del collar de la raíz se da a través de raíces interconectadas. 